\title{
Peritoneal Transport of Cefonicid
}

\author{
GENE D. MORSE, ${ }^{1 \dagger *}{ }^{*}$ TIMOTHY LANE, ${ }^{2,3}$ DAWN K. NAIRN, ${ }^{1}$ J. DETERDING, ${ }^{2}$ J. CURRY,${ }^{2}$ AND \\ PETER GAL ${ }^{2,4,5}$ \\ Departments of Pharmacy and Medicine, State University of New York at Buffalo, Erie County Medical Center, Buffalo, \\ New York 14215, Area Health Education Center ${ }^{4}$ and The Moses H. Cone Memorial Hospital, ${ }^{2}$ Greensboro, North \\ Carolina 27401; and School of Medicine ${ }^{3}$ and School of Pharmacy, ${ }^{5}$ University of North Carolina-Chapel Hill,
} Chapel Hill, North Carolina 27514

Received 29 September 1986/Accepted 18 November 1986

\begin{abstract}
The pharmacokinetic characteristics of cefonicid, a highly protein-bound expanded-spectrum cephalosporin, were examined in six noninfected, clinically stable patients undergoing continuous ambulatory peritoneal dialysis. After a 1.0-g intravenous dose of cefonicid, the mean concentrations in serum were $105 \pm 25$ and 35.6 $\pm 14.4 \mu \mathrm{g} / \mathrm{ml}$ at 3 and $72 \mathrm{~h}$, respectively. Despite a prolonged half-life in serum of $49.7 \pm 18 \mathrm{~h}$, the penetration into peritoneal fluid was low. The average concentration in dialysate over the $72-\mathrm{h}$ study period was $2.7 \mu \mathrm{g} / \mathrm{ml}$. The serum clearance was $2.6 \pm 1.0 \mathrm{ml} / \mathrm{min}$, and the distribution volume was $0.14 \pm 0.02$ liter/ $\mathrm{kg}$. Dosage recommendations and clinical considerations for cefonicid use in continuous ambulatory peritoneal dialysis patients are discussed.
\end{abstract}

Bacterial peritonitis predominantly caused by staphylococcal species is a frequent complication of continuous ambulatory peritoneal dialysis (CAPD). Cephalosporins are commonly prescribed for the treatment of this complication. Antibiotics which can be administered on an infrequent basis are desirable to avoid hospitalization and simplify the treatment regimen for the convenience of the patient. In addition, an antibiotic which does not require administration in every dialysis exchange would decrease potential contamination caused by repeated admixture with dialysate fluid (11).

Cefonicid is a long-acting cephalosporin with a half-life in serum of 3.5 to $4.5 \mathrm{~h}$ in patients with normal renal function $(4,8)$. The half-life is further prolonged as creatinine clearance (CL) declines and has been noted to be as long as $70 \mathrm{~h}$ when creatinine CL is less than $5 \mathrm{ml} / \mathrm{min}$ (3). The present study was conducted to examine the pharmacokinetic characteristics of cefonicid in CAPD patients and to evaluate its potential for convenient intermittent intravenous therapy for CAPD-related peritonitis.

\section{MATERIALS AND METHODS}

Six stable CAPD patients with no clinical signs or symptoms of peritonitis were admitted to the study after informed consent was obtained. Patients were excluded if they had previous beta-lactam allergy, antibiotic therapy within the past 2 weeks, severe cardiac (clinical congestive failure) or hepatic (twice normal serum levels of alanine transferase, aspartate aminotransferase, or both) dysfunction, or abnormal coagulation (prothrombin time or partial thromboplastin time of $5 \mathrm{~s}$ greater than control) parameters.

An indwelling venous catheter was placed in the arm contralateral to the infusion site, and a 1.0-g dose of cefonicid was administered over $8 \mathrm{~min}$. Blood samples were obtained at $0,3,6$ (end of first dialysis period), 9, 12 (end of second dwell period), 24,48 , and $72 \mathrm{~h}$. CAPD was continued throughout the study period with $q 4 h$ to $q 8 h$ exchanges

\footnotetext{
* Corresponding author.

$\uparrow$ Present address: State University of New York at Buffalo, 310 Cooke Hall, Amherst, NY 14260.
}

based on individual requirements. All dialysate drainage was measured, and a sample was saved. Blood samples were allowed to clot, and then serum was obtained by centrifugation. Serum and dialysate samples were stored at $-30^{\circ} \mathrm{C}$ until assayed.

Analytical-grade cefonicid (Smith Kline \& French Laboratories, Philadelphia, $\mathrm{Pa}$.) was measured by highperformance liquid chromatography with a modification of a previously reported assay (6). To $0.5 \mathrm{ml}$ of sample (serum or dialysate), $0.2 \mathrm{ml}$ of internal standard (cefazolin) and $1 \mathrm{ml}$ of acetonitrile were added. The mixture was vortexed for $15 \mathrm{~s}$, shaken for $5 \mathrm{~min}$, and centrifuged $(1,200 \times g ; 5 \mathrm{~min})$. To the supernatant, $2 \mathrm{ml}$ of methylene chloride was added, and the mixture was vortexed, shaken, and centrifuged as described above. A 20- $\mu$ l quantity of the upper aqueous phase was injected onto a Varian Micropak C-18 column (Varian Laboratories, Walnut Creek, Calif.). A mobile phase of $1 \%$ methanol in $2 \mathrm{M}$ sodium acetate ( $\mathrm{pH} 5.2$ ) was run at a flow rate of $1 \mathrm{ml} / \mathrm{min}$, and cefonicid was monitored at $210 \mathrm{~nm}$. The intraday and interday relative standard deviation was less than $7 \%$.

Data on concentration in serum were entered into the LAGRAN program (9) to determine the area under the serum concentration versus time curve (AUC) and the serum concentration $\times$ time versus time curve (area under the moment curve, AUMC). Total CL, volume of distribution at steady-state $\left(V_{\mathrm{ss}}\right)$, and the serum half-life $\left(t_{1 / 2}\right)$ were determined as follows: $\mathrm{CL}=\operatorname{dose} / \mathrm{AUC}_{0}{ }^{t}, V_{\mathrm{ss}}=t$. CL, $t_{1 / 2}=$ $0.693 / \lambda$, where dose is the administered dose, $t$ is the mean residence time (AUMC/AUC), and $\lambda$ is the slope of the elimination phase. In addition, the ratio of the amount of drug $\left(X_{D}\right)$ recovered via CAPD to the $\mathrm{AUC}_{0}{ }^{t}$ was determined.

\section{RESULTS}

Cefonicid administration was well-tolerated by all of the CAPD patients. A representative serum and dialysate concentration versus time profile is illustrated in Fig. 1. Cefonicid concentrations in serum displayed a linear decline over time, with mean values of $105 \pm 25 \mu \mathrm{g} / \mathrm{ml}$ at $3 \mathrm{~h}, 73.3 \pm$ 


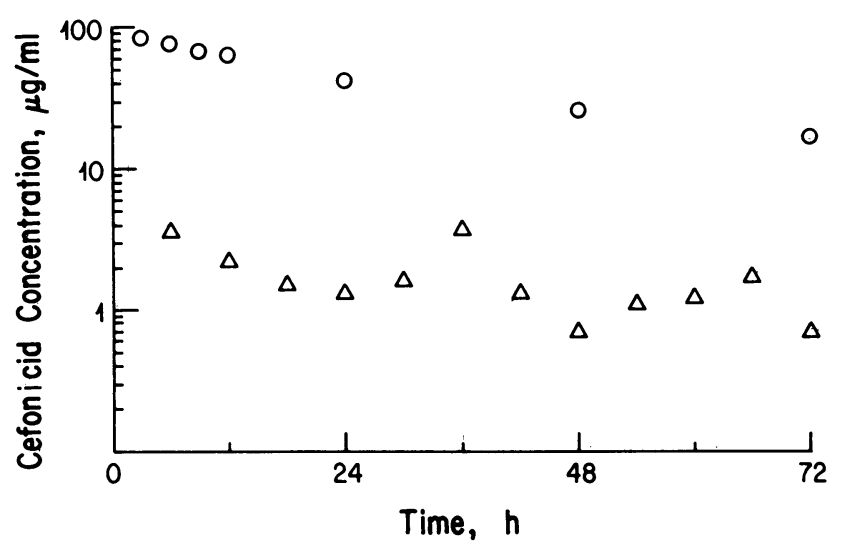

FIG. 1. Representative serum $(O)$ and end-dialysate $(\triangle)$ concentration versus time profile after a $1.0-\mathrm{g}$ intravenous dose of cefonicid. End-dialysate concentrations reflect accumulation of drig throughout the dwell period.

$19.2 \mu \mathrm{g} / \mathrm{ml}$ at $24 \mathrm{~h}$, and $35.6 \pm 14.4 \mu \mathrm{g} / \mathrm{ml}$ at $72 \mathrm{~h}$. The mean CL was $0.04 \pm 0.01 \mathrm{ml} / \mathrm{min}$ per $70 \mathrm{~kg}$, and the mean $V_{\text {ss }}$ was $0.14 \pm 0.02$ liter $/ \mathrm{kg}$. The serum $t_{1 / 2}$ was $49.7 \pm 18 \mathrm{~h}$.

Cefonicid diffused slowly into peritoneal fluid, with five of six patients displaying less than $1 \mu \mathrm{g} / \mathrm{ml}$ at the end of the initial dwell period. During subsequent dwell periods, cefonicid attained mean end-dwell dialysate concentrations of $4.1 \pm 3.1 \mu \mathrm{g} / \mathrm{ml}$ at $24 \mathrm{~h}, 2.3 \pm 1.7 \mu \mathrm{g} / \mathrm{ml}$ at $48 \mathrm{~h}$, and 1.5 $\pm 1.1 \mu \mathrm{g} / \mathrm{ml}$ at $72 \mathrm{~h}$. The mean $X_{D}$ :AUC value was $0.26 \pm$ $0.08 \mathrm{ml} / \mathrm{min}$ per $70 \mathrm{~kg}$, and the mean percent of dose recovered via CAPD was $6.5 \pm 3.2 \%$. Individual cefonicid concentrations and pharmacokinetics are summarized in Tables 1 and 2, respectively.

\section{DISCUSSION}

In comparison with the $t_{1 / 2}$ of 3 to $4 \mathrm{~h}$ in normal humans, the half-life of cefonicid in CAPD patients is markedly prolonged to $50 \mathrm{~h}$. This value is similar but somewhat lower than that during hemodialysis, for which a $t_{1 / 2}$ of $70 \mathrm{~h}$ has been reported (3). The major factor which prolongs the cefonicid $t_{1 / 2}$ is the lack of a renal excretory route, upon which this drug is heavily dependent for elimination. Serum CL values of $25 \mathrm{ml} / \mathrm{min}$ in healthy subjects (3) far exceed the low values found during CAPD in the present study $(2.6$ $\mathrm{ml} / \mathrm{min}$ ) and during hemodialysis (1.9 $\mathrm{ml} / \mathrm{min})(3)$. The volume of distribution of cefonicid in CAPD patients $(0.14$
TABLE 2. Individual cefonicid pharmacokinetic parameters in CAPD patients after intravenous administration

\begin{tabular}{cllll}
\hline Patient no. & $\begin{array}{c}\text { CL }(\mathrm{ml} / \mathrm{min} \\
\text { per 70 kg) }\end{array}$ & $\begin{array}{c}V_{\mathrm{ss}} \\
\text { (liter/kg) }\end{array}$ & $t_{1 / 2}(\mathrm{~h})$ & $\begin{array}{c}X_{D} / \mathrm{AUC} \\
(\mathrm{ml} / \mathrm{min} \text { per } \\
70 \mathrm{~kg})\end{array}$ \\
\hline 1 & 0.04 & 0.13 & 37.7 & 0.22 \\
2 & 0.02 & 0.13 & 75.5 & 0.29 \\
3 & 0.03 & 0.16 & 58.6 & 0.31 \\
4 & 0.04 & 0.11 & 27.8 & 0.17 \\
5 & 0.03 & 0.15 & 59.2 & 0.21 \\
6 & 0.05 & 0.16 & 38.4 & 0.26 \\
Mean (SD) & $0.04(0.01)$ & $0.14(0.02)$ & $49.6(17.9)$ & $0.24(0.05)$ \\
\hline
\end{tabular}

liter $/ \mathrm{kg}$ ) is similar to that seen in hemodialysis patients, chronic renal failure, and normal humans (3). Therefore, it is apparent that the prolonged serum $t_{1 / 2}$ is due to decreased $\mathrm{CL}$ and not to changes in distribution volume.

Despite the prolonged serum $t_{1 / 2}$ and the resultant elevation of concentrations in serum, concentrations in dialysate were variable and generally low among the study patients. The variability found for peritoneal drug concentrations is consistent with the results of other studies that have found a wide range of tissue-to-serum ratios in bone, uterine tissue, gallbladder, wounds, pus, pleural fluid, and breast milk (5). The concentrations of cefonicid in peritoneal fluid, however, are lower than those reported in other tissue compartments. This finding may reflect the more complex nature of the peritoneal membrane and the numerous factors which affect solute diffusion from serum into dialysate (7). Although not studied in renal failure patients, the high degree of serum protein binding of cefonicid in normal serum (98\%) is a prime factor which may contribute to slower diffusion into dialysate (2). The low concentrations in dialysate are of some concern, in that the MIC for 50\% of Staphylococcus aureus strains tested ranges from 2 to $4 \mu \mathrm{g} / \mathrm{ml}$ and that for $50 \%$ of Staphylococcus epidermidis strains tested ranges from 4 to 8 $\mu \mathrm{g} / \mathrm{ml}$ (1). Although the significance of achieving concentrations in dialysate above the MIC for a specific pathogen remains unclear, many CAPD centers advocate the continuous intraperitoneal administration of antibiotics to overcome subtherapeutic concentrations in dialysate (10). More recently, the need for continuously adding cephalosporin antibiotics to dialysate has been questioned and an alternative treatment regimen with a single daily intraperitoneal dose has been suggested (11). In addition, antibiotic which is present in dialysate is primarily unbound to protein (5a).

TABLE 1. Concentrations in serum and dialysate after intravenous administration of cefonicid to CAPD patients

\begin{tabular}{|c|c|c|c|c|c|c|c|c|}
\hline \multirow{3}{*}{ Patient no. } & \multicolumn{8}{|c|}{ Cefonicid concn $(\mu \mathrm{g} / \mathrm{ml})^{a}$ at: } \\
\hline & \multicolumn{2}{|c|}{$12 \mathrm{~h}$} & \multicolumn{2}{|c|}{$24 \mathrm{~h}$} & \multicolumn{2}{|c|}{$48 \mathrm{~h}$} & \multicolumn{2}{|c|}{$72 \mathrm{~h}$} \\
\hline & $\mathbf{S}$ & $\mathrm{D}$ & $\mathbf{S}$ & D & $\mathbf{S}$ & D & $\mathbf{S}$ & $\mathrm{D}$ \\
\hline 1 & 86.5 & 4.5 & 77.4 & 2.9 & 51.1 & 1.8 & 32.0 & $\mathrm{ND}^{b}$ \\
\hline 2 & 109 & ND & 84.4 & 3.9 & 65.0 & 5.1 & 54.4 & 3.5 \\
\hline 3 & 109 & 7.8 & 79.7 & 8.2 & 63.7 & 3.4 & 45.2 & 1.4 \\
\hline 4 & 113 & 3.9 & 95.8 & 7.4 & 51.9 & 1.2 & 29.0 & 1.0 \\
\hline 5 & 60.0 & 0.9 & 60.8 & 0.6 & 40.6 & 1.6 & $\mathrm{NC}^{c}$ & 1.4 \\
\hline 6 & 64.6 & 2.2 & 41.6 & 1.3 & 26.0 & 0.7 & 17.5 & 1.7 \\
\hline Mean (SD) & $90.4(23.7)$ & $3.9(2.6)$ & $73.3(19.2)$ & $4.1(3.1)$ & $49.7(14.7)$ & $2.3(1.7)$ & $35.6(14.4)$ & $1.5(1.1)$ \\
\hline
\end{tabular}

${ }^{a} \mathrm{~S}$, Concentration in serum; $\mathrm{D}$, concentration in dialysate.

${ }^{b}$ ND, Not detectable.

$c$ NC, Not collected. 
Therefore, in the case of cefonicid, a concentration of 2 $\mu \mathrm{g} / \mathrm{ml}$ in dialysate may be equivalent in activity to $100 \mu \mathrm{g} / \mathrm{ml}$ in serum due to drug binding to albumin. Lastly, it is likely that cefonicid concentrations would be greater in the presence of peritoneal inflammation.

In summary, cefonicid CL is markedly impaired during CAPD. Concentrations in serum are elevated, but concentrations in dialysate are comparatively low after intravenous administration. Factors other than the absolute drug concentration in dialysate, such as host defenses, peritoneal tissue drug concentration, and minimal dialysate protein binding, may contribute to eradication of the infecting organism. It would be worthwhile to examine the in vitro bactericidal activity of dialysate with concentrations of cefonicid in the 1to $2-\mu \mathrm{g} / \mathrm{ml}$ range against gram-positive pathogens as a prelude to further clinical studies in patients with peritonitis.

\section{ACKNOWLEDGMENTS}

The secretarial support of Beverly Speller and Cheryl Wild is appreciated.

This work was supported by a grant from Smith Kline \& French Laboratories.

\section{LITERATURE CITED}

1. Actor, P. 1984. In vitro experience with cefonicid. Rev. Infect. Dis. 6(Suppl. 4):783-790.

2. Actor, P., J. V. Uri, I. Zajac, J. R. Guarini, L. Phillips, D. H. Pitkin, D. A. Berges, G. L. Dunn, J. R. E. Hoover, and J. A. Weisbach. 1978. SK\&F 75073, new parenteral broad-spectrum cephalosporin with high and prolonged serum levels. Antimi- crob. Agents Chemother. 13:784-790.

3. Barriere, S. L., J. G. Gambertoglio, D. P. Álexander, R. J. Stagg, and J. E. Conte. 1984. Pharmacokinetic disposition of cefonicid in patients with renal failure and receiving hemodialysis. Rev. Infect. Dis. 6(Suppl. 4):809-815.

4. Barriere, S. L., G. J. Hatheway, J. G. Gambertoglio, E. T. Lin, and J. E. Conte, Jr. 1982. Pharmacokinetics of cefonicid, a new broad-spectrum cephalosporin. Antimicrob. Agents Chemother. 21:935-938.

5. Lou, M. A., Y. H. Wu, L. S. Jacob, and O. H. Pitkin. 1984. Penetration of cefonicid into human breast milk and various body fluids and tissues. Rev. Infect. Dis. 6(Suppl. 4):816-820.

5a.Morse, G. D., C. Rowinski, P. E. Lieveld, and J. J. Walshe. 1986 Drug-protein binding during continuous ambulatory peritoneal dialysis. Perit. Dial. Bull. 6:144-147.

6. Nightingale, C. H., R. Quintiliani, M. N. Dudley, P. Gough, M. Kickingbotham, N. Schuddekopf-Jordan, E. Rose, and $M$. Toscani. 1984. Tissue penetration and half-life of cefonicid. Rev. Infect. Dis. 6(Suppl. 4):821-828.

7. Nolph; N. D. 1979. Peritoneal clearance. J. Lab. Clin. Med. 94:519-525.

8. Pitkin, D., J. Dubb, P. Actor, F. Alexander, S. Ehrlich, R. Familiar, and R. Stote. 1981. Kinetics and renal handling of cefonicid. Clin. Pharmacol. Ther. 30:587-593.

9. Rocci, M. L., and W. J. Jusko. 1983. LAGRAN program for area and moments in pharmacokinetic analysis. Comp. Prog. Biomed. 16:203-216.

10. Vas, S. I. 1983. Microbiological aspects of chronic ambulatory peritoneal dialysis. Kidney Int. 23:83-92.

11. Walshe, J. J., G. D. Morse, P. E. Lieveld, R. C. Venuto, and M. A. Apicella. 1985. Treatment of peritonitis in CAPD: rationale for an alternative antibiotic therapy based on kinetic analysis and clinical response. Adv. Peritoneal Dialysis 1985: 66-72. 